\title{
The Fate of Prisoners of War Between the Quran, Traditions of the Prophet Muhammad and Practice of the Islamic State in Iraq and Syria
}

\author{
Rebaz R. Khdir, PhD Candidate \\ School of Law, University of Minho, Braga-Portugal
}

Doi: 10.19044/esj.2017.v13n34p30 URL:http://dx.doi.org/10.19044/esj.2017.v13n34p30

\begin{abstract}
Humanitarian law is the law of armed conflict that has originated from the rules and costumes of the ancient religions and civilizations. Islam includes many rules that restrict war between combatants and prohibit the warfare methods cause superfluous harm. The Quran and prophet Muhammad command Muslims to release and ransom war prisoners based on their personal conditions. The Quran never encourages Muslims to enslavement neither does mention execution but Muslims often enslaved prisoners as a common phenomenon of the era and executed some few for their atrocities and dishonesty. ISIS captured many war prisoners after the commencement of its military attacks against Iraq and Syria in 2013. The group executed most of the prisoners for taking part in battle against them through shooting, beheading, hanging and burning alive. The article compares the ISIS practice with the commandments of the Quran and prophet Muhammad in respect of the fate of war prisoners.
\end{abstract}

Keywords : Humanitarian law, prisoners of war, the Quran, traditions of the prophet Muhammad, ISIS

\section{Introduction}

Modern international humanitarian law comprises of the rules and costumes that have been enshrined and practiced by the ancient religions and civilizations. Islam includes a set of humanitarian rules that have essentially sourced from the Quran and traditions of the prophet Muhammad. The rules generally regulate all the aspects of warfare. One of the normal consequences of every armed conflict is taking prisoners. The Quran and the prophet have adopted various commandments as to the treatment of war prisoners. The commandments range from adequate feeding, clothing, respecting their religious belief in captivity to prohibition of torture, release unconditionally or for a service and freedom after enslavement. 
The Islamic State in Iraq and Syria (ISIS) is the most radical modern Islamic group which has been listed among the terrorist organizations by almost all the world states. The group carried out intensive military attacks against Iraq and Syria from 2013 to 2014 and seized 12,000 to 35,000 miles from the two countries by August 2014 (Gilsinan, 2014). In the course of its military operations, ISIS captured many war prisoners. The group held the prisoners without food, water, defence and communication with their family members. The group's fighters tortured the prisoners through whipping, electrocuting and horrific psychological methods and executed most of them through shooting, beheading, hanging and burning alive.

There are, though, many books and manuscripts available as to the ISIS background, ideology, military forces and criminal records; there is still a lack of a comparative literature between ISIS and Islam in respect of adherence to humanitarian rules. Such a study helps to have a proper understanding of Islam and ISIS regarding the fate of war prisoners.

The article firstly addresses the relevant Quranic verses and traditions of the prophet Muhammad as to the fate of war prisoners. It later reports the ISIS criminal records of torture and execution of prisoners. It finally provides a comparative conclusion between the commandments of the Quran and prophet Muhammad and practice of ISIS.

\section{Islam and humanitarian rules}

Humanitarian law is generally defined as the law of war or armed conflict. It is basically a legal framework which comprises of the rules and principles that humanize war through protecting persons, who are not or no longer participating in armed conflict, and regulating means and methods of warfare. International humanitarian law was first codified in the nineteenth century (Geneva Convention I) but it has initially originated from the customs and principles of the ancient religions and civilizations.

Islam is the extension of the Abrahamic religions which are based on the idea of monotheism (The Quran, 3:84; 42:13). The message of Islam is essentially similar with what the other prophets brought and taught their peoples for but it is believed by its adherents to be the final and universal divine call (The Quran, 33:40; 4:47; 3:19, 85). The main sources of Islam are the Quran and traditions of the prophet Muhammad. The secondary sources are consensus, analogical reason, juristic discretion, public interest, inference, reason and customs.

Islam generally does not allow waging war except within jihad. Jihad is though very extensive that includes every effort exerted for God (The Quran, 29:69; 22:78; 61:11; al-Bukhārī, 1997: Hadith No. 2784-2786); it definitely entails combat (The Quran, 22:39-40; 2: 190-193; 9:5, 123). Combative jihad is today restricted to defend Muslim communities and 
territories of Islamic countries from aggression (al-Buti, 1995: 44; Kabbani). In addition, jihad must be accompanied with adherence to humanitarian rules prescribed in the Quran, traditions of the prophet, practices of the early predecessors and jurisprudential literature.

The classical and medieval Islamic scholarship characterized combative jihad based on the religious status of their enemy armies. They set forth different rules for Muslims, the people of books and polytheists. Muslim warriors had to adhere humanitarian rules more strictly in their internal conflicts and the rules were similarly stricter in international conflicts against the books' people than the ones were applicable for the polytheists. However, the distinction seems to be less important these days and the rules are equally applicable regardless of the religious status of belligerent combatants.

Islamic humanitarian rules regulate every aspect of warfare from protection of civilians and noncombatants and prohibition of attacking civilian objects to mutilation, cruel treatment, torture, besiege and starvation and killing prisoners of war. The Quran Says: "And fight in the way of Allah with those who fight against you and do not transgress. Indeed, Allah does not love the transgressors" (The Quran, 2:190). The prophet instructed the Muslim troops in fighting against the Byzantine army that "in avenging the injuries inflicted upon us molest not the harmless inmates of domestic seclusion; spare the weakness of the female sex; injure not the infants at the breast or those who are ill in bed. Refrain from demolishing the houses of the unresisting inhabitants; destroy not the means of their subsistence, nor their fruit-trees and touch not the palm ... and do not mutilate bodies and do not kill children" (Bennoune, 1994: 624; Dahlan,1996: 236; Munir, 2011: 15).

The verse generally limits war to the imminent threat of or actual act of aggression against Muslims and their land along with the adherence to the principles of necessity and proportionality. It prevents needless harm through the determination of people who can possibly be fought with and general prohibition of transgression during armed conflict. The instructions of the prophet illustrate the Quranic comprehensive term of transgression and define it as committing certain criminal acts during armed conflict that Muslims must refrain from.

\section{Islam and prisoners of war}

One of the possible consequences of war is taking prisoners. Prisoners can simply be defined as combatants fighting for a side of a conflict and captured by their belligerent power. The Quran and traditions of the prophet Muhammad entail various humanitarian rules which deal with war prisoners. The rules guide Muslims to capture adversary warriors only after defeating them, treat them nice in captivity and release them upon the 
termination of hostilities. The release of prisoners could be out of mercy, upon ransom or a charitable act after enslavement in accordance with personal conditions of prisoners.

\section{The Quran and the fate of war prisoners}

The Quran provides extensive commandments as to the treatment of war prisoners. Some of the commandments leave some necessary spaces for juristic interpretation based on the personal conditions of prisoners. Yet, the interpretation, in any case, must not exceed human rights and humanitarian limits. The Quran, as a general rule, allows Muslims to capture belligerent warriors in battle, as it says:

"It is not for a prophet to have (take) captives (during battle) until he has thoroughly subdued the land..." (The Quran, 8:67).

The verse is a clear guidance to Muslims regarding the time that they may capture warriors from their adversary armies. It orders Muslims to fight their belligerents until they overcome them and later captivate the defeated warriors. The implications behind this verse are ending the threat of aggression Muslims face as a priority and having military ascendancy to capture adversary combatants.

The Quran also says:

"So, when you meet (encounter) those who disbelieve (in battle) strike (their) necks until when you have subdued (overcome) them (fully), then bind (tighten) firmly (their) bond(s)..." (The Quran, 47:4).

This verse is interrelated with the previous verse and accordingly Muslims must take captives in actual battles after defeating adversary armies and before the termination of hostilities.

The Quran advices Muslims how to treat prisoners in captivity and says:

"They righteous shall... offer food, for the love of Him (Allah), to the needy, the orphan and the captive, (saying): We feed you for the countenance of Allah alone. We desire from you neither reward nor gratitude" (The Quran, 76:5-9).

The verse explicitly requires Muslims to show mercy and kindness to prisoners through feeding so that they would achieve God's reward. The verse later created many noble humanitarian customs as to the treatment of war prisoners in the history of Islam.

The Quran further illustrates the fate of prisoners and says:

"...Thereafter (free them) either a favor (an act of grace) or (for) ransom until the war lays down (terminates) its burden..." (The Quran, 47:4).

The verse contains a clear determination as to the fate of prisoners. It commands Muslims to release prisoners in any case after the cessation of 
hostilities. The verse moreover instructs Muslims how to release prisoners. It provides unconditional release out of pity and release for ransom. The verse prioritizes gratuitous release over ransoming prisoners by mentioning it first. It does not mention enslavement neither does refer to execution, even though they were practiced by Muslims for some reasons.

As we discussed before, there is no explicit permission for enslavement of prisoners within the Quranic verses but prisoners were enslaved by Muslims. Muslims often, along with combatants, captured women and children from their enemies and later divided them as slaves among the fighters participated in battles. Islamic scholars generally define prisoners as spoils of war. They distinguish not between the combatant prisoners and civilian prisoners. In the early Islamic history, there were enslavement cases of prisoners but most of the enslaved were civilians and not captured warriors. Yet, the Quran never adopted slavery as a social system neither did encourage Muslims to practice it. Rather, slavery was a social phenomenon of that era. Besides this, Islam established strong ideological motivations to abolish it but Muslims did not completely desist it until the global abolishment of slavery. The Quran includes many verses which strongly encourage Muslims to treat slaves humanely and free them, as it says:

"... (do) good to the parents, the relatives, the orphans, the poor, the neighbors (who are) near, the neighbors (who are) far, the companion at your side, the traveler and what your right hands possess (slaves)..." (The Quran, 4:36).

"The charities are (only) for the poor, the needy, (charity) collectors, (those whose) hearts are inclined (towards Islam), (freeing) the necks (slaves), debtors, (spending) in the way of Allah and the wayfarer..." (The Quran, 9:60).

"...But the righteous (is he) who believes in Allah, the Last Day (Judgment Day), the Angels, the Book (Scripture), the Prophets and gives wealth, in spite of love for Him (Allah), to the near relatives, the orphans, the needy, the traveler, those who ask (for help), and in freeing the necks (slaves)..." (The Quran, 2:177).

"... And whoever killed a believer by mistake, then he (must) free a believing slave and pay the blood money to the family (of the victim) unless they (the family) remits it (in) charity. But if he (the victim) was from a people hostile to you and he was a believer, then the freeing (of) a believing slave (is sufficient). And if he (the victim) was from a people (and) between you there was a covenant, then pay the blood money to his family and free a believing slave..." (The Quran, 4:92). 
"And those who declare zihar from (to) their wives (equating their wives to their mothers) and go back on what they said, (they shall) free a neck (slave) before they touch each other..." (The Quran, 58:3).

The abovementioned verses consider the freeing of a slave as a highly charitable act which leads to expiation of sins and great benevolence.

\section{The prophet Muhammad and the fate of war prisoners}

The issue of prisoners of war might have been a complex issue in the early periods of Islam due to the lack of precedent norms, principles and rules on the one hand and the crimes that some of the prisoners had before committed against Muslims on the other hand.

In the battle of Badr (624 A.D.), Muslims captured 70 warriors (alBukhārī , 1997: Hadith No. 3039) from the Meccan pagan tribe of Quraysh. The prophet later distributed the captives among his companions (Ibn Ishaq' 2004: 309) and asked them to treat the prisoners nice (al-Tabarani, 1994: Hadith No.18444). The prophet further asked his companions to offer food to the prisoners from what they themselves had (Ali , 2010: 63) and clothe them from what they themselves used to wear (al-Bukhārī, 1997: Hadith No. 3008). During the time of the prophet, there was no prison and the prisoners were held in private houses and mosques (Ennaji, 2013: 226). The prisoners had the right to remain on their religious faith and compulsory conversion was a prohibited act based on the Quranic commandment (The Quran, 2:256; al-Bukhārī, 1997: Hadith No. 4372). The prophet prevented separating prisoners, who belonged to the same family, (at-Tirmidhi, 2007: Hadith No. 1283; Ibn Mâjah, 2007: Hadith No. 2250; Abu Dawd, 2008: Hadith No. 2696) and torture in all forms and in any time (Muslim, 2007: Hadith No. 2613). The early Islamic records indicate that Muslims allowed representatives of their belligerent armies to visit their prisoners within the territory of Islamic state for counting them (Yamani, 1985: 210). In the battles of Uhud (625 A.D.), Khaybar (629 A.D.), Hunayn (630 A.D.) and the later battles, Muslims captured many prisoners and treated them as they had treated the prisoners of Badr.

Muslims were responsible for the life of prisoners until the prophet would take a decision regarding their fate. The prophet released prisoners in various ways. He released some out of mercy and some others for ransom as the Quran ordered. The prophet interpreted the Quranic term of ransom based on the personal conditions of prisoners. The ransom of the prophet could form money, service to the Muslim community and prisoner exchange.

After the battle of Badr, the prophet consulted with his close companions Abu Bakr al-Sddiq and Umar Ibn al-Khattab as to the fate of the prisoners. Abu Bakr suggested release on the condition of ransom while Umar suggested killing them (Muslim, 2007: Hadith No. 1763; at-Tirmidhi, 
2007: Hadith No. 1567). The prophet later ransomed the prisoners for their freedom. He required the rich prisoners to pay an amount of money based on their financial situation. He required the poor but literate prisoners to teach ten Muslim children to read and write. He released the ones who were neither rich nor literate unconditionally (Ibn Ishaq, 2004: 741; The History of al-Tabari, 1987: 69-72; Siddiqi, 1989: 87; Doi, 1983: 95; Khan, 2011: 112). The prophet also practiced prisoner exchange. In several occasions, he released non-Muslim prisoners for his captured companions (Munir, 2010: 466).

The prophet never punished prisoners because they had participated in battles against Muslims and prohibited their execution on this account. It is narrated that the prophet has, when his military commander Khãlid Ibn alWalid killed some captives from the tribe of Jadhimah, said "O Allãh! I am free from what Khãlid has done” (al-Bukhārī, 1997: Hadith No. 4339).

However, Muslims, based on the order of the prophet, executed some prisoners for some crimes and dishonesty during or out of battles. Among the Badr prisoners, Muslims executed two for persecuting Muslims in Makkah (Abu Dawd, 2008: Hadith No. 2686; Al-Mubarakpuri, 1996: 229). They also executed two prisoners in the battle of Uhud and one other in Khaibar battle for breaking promises, spying over the Muslim army and breaching treaty rules (Al-Mubarakpuri, 1996: 291, 372). The most complex case was the mass execution of the Jewish tribe of Qurayza in Medina. After the Qurayza breached its peace pact with the other Medina tribes and sided the Quraysh in the battle of Trench (627 A.D.) against Medina, Muslims besieged the Qurayza's neighborhood for 25 days (Ibn Ishaq, 2004: 458-461). Later, both sides agreed on the appointment of an arbitrator to decide on the case. The arbitrator was appointed from the Aws tribe that was the alley of the Qurayza. The arbitrator charged the tribe members with treason and condemned the male members, who were numbered between 600-700, to death (Muslim, 2007: Hadith No. 1768; al-Bukhārī, 1997: Hadith No. 4121; Ibn Ishaq, 2004: 462-464).

As we noted before, Muslims often enslaved people including prisoners of war. The arbitrator, in the case of the Qurayza tribe, decided on the enslavement of the tribe's women and children who were about 1000 people (Kister, 1986: 93). The Muslim army captivated 100 families in another battle against the tribe of al-Mustaliq (626 A.D.). They released all after the prophet married the daughter of the tribe's chieftain (The History of al-Tabari, 1987: 56-57; Al-Mubarakpuri, 1996: 330). In the Hunayn battle, Muslims enslaved 6000 people from the Hawazin tribe but they freed them soon after the tribe converted to Islam (Ibn Ishaq, 2004:592-596; al-Bukhārī, 1997: Hadith No. 3131,3132). However, the practice of slavery in Islamic was essentially different from the slavery practiced by the other civilizations. 
In the Islamic tradition, slaves were entitled to the same food, cloth and dwell of their masters. Muslims never imposed forced labor or any work upon them that they themselves would not be able to do so. The freeing of slaves was inevitable after they would accept Islam or when there was a certainty that their freedom would not endanger the security and peace of Muslims. The prophet, along with the Quranic verses, encouraged Muslims to treat slaves humanly, feed them adequately, clothe them properly and set them free if they were not dangerous and harmful to the Muslim society. The prophet is reported to have said:

"No one will enter paradise who ... mistreats his slaves..." (Bin Hanbal, 2012: Hadith No. 32).

"whoever slaps his slave or beats him, his expiation is to manumit him" (Muslim, 2007: Hadith No. 1657).

"They (slaves) are your brothers whom Allah has placed under your control, so feed them what you eat, and clothe them with what you wear, and do not burden them with more than they can bear; if you do burden them, then help them" (Muslim, 2007: Hadith No. 1661).

"Free the captives (slaves), feed the hungry and pay a visit to the sick" (al-Bukhārī, 1997: Hadith No. 3046).

\section{ISIS and prisoners of war}

ISIS is an extremist Islamic group which was formed on 8 April 2013 (Mourtada and Gladstone, 2013). However, it had operated under different names from the beginning of 2000s (Zelin, 2014: 1-4; Bunzel, 2015: 13-25; Hashim, 2014: 2-11). The group waged a very indiscriminate war against Iraq and Syria under the leadership of the Iraqi jihadi Abu Bakr al-Baghdadi between 2013 and 2014. Consequently, it took control of half of Syria and one third of Iraq and announced an Islamic Caliphate on 29 June 2014 (This is the promise of Allah, 2014).

The international human rights bodies including the United Nations Assistant Mission for Iraq (UNAMI) and the Office of the Higher Commission for Human Rights (OHCHR), Human Rights Watch, Amnesty International and United Nations Human Rights Council (UNHRC) gathered many authentic evidences that indicated ISIS took many combatants and civilians prisoners during its military operations against the two countries. The majority of ISIS prisoners were possibly from the Iraqi armed forces, Iraqi Kurdish forces known as the Peshmerga forces, Syrian regime military forces, government opposition group of the Free Syrian Army (FSA), Syrian Kurdish forces knowns as the Yekineyên Parastina Gel (YPJ) (People's Protection Units) and Syrian Democratic Forces (SDF) supported by the international coalition. The group captured some civilians for being affiliated 
with the Iraqi and Syrian military forces and the rival armed groups and some others based on their religious faith.

According to the available evidences, ISIS held the prisoners in various places across Iraq and Syria including captured prisons, military bases, hospitals, schools and civilian houses (UNHRC, 14 November 2014: 7). Some former prisoners have reported that the places were usually overcrowded and dirty. The group left the prisoners without lights, adequate food, medical care, defence counsel and any communication with outside of the cells (UNHRC, 13 August 2014: 11). Amnesty international has documented various methods that the group used to torture prisoners. Accordingly, the ISIS fighters flogged prisoners with belts, cables and electric shocks (Amnesty International, 2013). The UNHRC reported that the group often hanged prisoners by their arms (UNHRC, 14 November 2014: 7). Some former detainees exposed some psychological torturing methods. According to them, the ISIS prison guards constantly talked about the group's revenge from them, placed knives on their necks and showed severed heads with the threat of similar fate to them (Shammas, 2016).

Most of the available evidences regarding the torture of war prisoners, however, have been documented in Syria; ISIS adopted and practiced the same policy in Iraq. The reason was perhaps that the focus of the human rights bodies, in Iraq, was more on the unspeakable mass executions of prisoners by the group.

\section{ISIS and the fate of war prisoners}

After ISIS entered Iraq from the Syrian borders on 10 June 2014 (UNAMI and OHCHR, 5 June-5 July 2014: 3), it started retaliating against the former soldiers, former members of the security forces, former police officers and former pilots and air force recruits who were trapped within the controlled cities. The group also captured many others including peshmerga fighters during battle. ISIS attacked the northern Iraqi Ninewah province and abducted thousands of Christians, Yazidis, Shi'a Shabaks and Turkmens for their distinct religious belief and practice (UNAMI and OHCHR, 6 July-10 September 2014: 11-17; UNAMI and OHCHR, August 2016: 6-7).

The group established irregular courts, known as the Shari'a courts, to decide on the fate of victims (UNAMI and OHCHR, 6 July-10 September 2014: 6; UNAMI and OHCHR, 1 May-31 October 2015: 11-12). According to Amnesty International, the courts never provided victims with due process rights (Amnesty International, 2013). The fate of prisoners was based on their religious status before the courts. The courts could decide on amnesty, execution, ransom or enslavement (Varghese, 2014) as mentioned in the Quran and traditions of the prophet Muhammad but they applied the rules as strict as possible. 
ISIS never implemented gratuitous release despite being the most recommended Quranic and prophetic choice. The group though ransomed some few Yazidi security guards and civilians but it demanded millions of dollars from their families (Human Rights Watch, 19 July 2014; UNAMI and OHCHR, 5 June-5 July 2014: 19; UNAMI and OHCHR, I1 December 201430 April 2015: 20). The ISIS fighters often practiced prisoner exchange in Syria but there is no evidence shows a similar practice in Iraq. ISIS widely enslaved people particularly the Yazidi members (The Revival of Slavery, 2014: 14-15). The group enslaved more than 6000 Yazidis mostly women and children (UNAMI and OHCHR, August 2016:7). The fighters enforced the enslaved women to convert to Islam. The ones who converted were faced enforced marriage and the ones who refused were held in sexual slavery (UNAMI and OHCHR, I1 December 2014-30 April 2015: 20).

According to the reported criminal incidents, ISIS executed most of the prisoners captured during battle and the ones who had fought against the group before. The group carried out the executions through the most brutal methods of shooting at close range, beheading, hanging and burning victims alive.

The UNAMI and OHCHR reported many execution incidents by ISIS between June and July 2014. According to the reports, ISIS killed hundreds of war prisoners in Tikrit and Awenat-Salahaddin and Riyadh and RashadKirkuk (UNAMI and OHCHR, 5 June-5 July 2014: 10-11; UNAMI and OHCHR, 6 July-10 September 2014: 6).

ISIS published some photographs on 14 June 2014 that showed mass executions of air force recruits in the Spiker military airbase in Salahaddin. The group, though, claimed the responsibility for the execution of 1700 prisoners (UNAMI and OHCHR, 6 July-10 September 2014: 6); Human Rights Watch estimated the victims to be between 125 and 150 prisoners (Human Rights Watch, 26 June 2014).

The group often carried out mass executions and later buried the victims in mass graves. Based on the UNAMI and OHCHR reports, people found hundreds of corpses of the executed war poisoners in Baquba-Kirkuk, Abbasiyah-Tikrit-Salahaddin, Jumela village-Salahaddin, Sulaiman BekKirkuk, Hawija-Kirkuk, Wahda-Diyala in July and August 2014 (UNAMI and OHCHR, 6 July-10 September 2014: 6-7).

ISIS published a video, in late August 2014, in which showing the behedging of a Kurdish Peshmerga fighter and threatening the execution of 14 others (Mamoun, 2014). In March 2015, the group released another video indicating the beheading of three other Peshmergas (Islamic State Video, 2015). The ISIS fighters, according to UNAMI and OHCHR, hanged a soldier from the Muadhaffen bridge in Fallujah, Anbar on 20 May 2015 after 
they captured him wounded during armed conflict (UNAMI and OHCHR, I May-31 October 2015: 12).

The group again carried out a series of mass executions of war prisoners in al-Wafa- Anbar, Tikrit-Salahaddin, al-Door-Salahaddin, AskiMosul, Badush prison-Mosul from December 2014 to March 2015 (UNAMI and OHCHR, I1 December 2014-30 April 2015: 11-12).

The ISIS fighters killed civilians for working with, supporting or providing information to the Iraqi Security and Kurdish Peshmerga forces. The group executed thousands of civilians for this reason in different areas of Mosul and Salahaddin from June 2014 to September 2015 (UNAMI and OHCHR, 5 June-5 July 2014: 9; UNAMI and OHCHR, I May-31 October 2015: 9). ISIS was also accused of abducting and killing many members of the government loyal tribes for the same reason. The fighters from the group executed hundreds from the Sunni tribes of Albu Nimr, al-Jaburi, Jumaili, Qaisi, and al-Douri in Anbar, Salahaddin and Mosul from October 2014 to April 2015 (Amnesty International, 2015: 193; UNAMI and OHCHR, 11 December 2014-30 April 2015: 12; UNAMI and OHCHR, I May-31 October 2015: 9).

ISIS similarly captured many civilians, government soldiers, fighters of and people affiliated with the other rebel groups in Syria. The group never released prisoners out of grace neither did ransom them except some few unsuccessful demands of millions of dollars regarding some Christian civilians and international hostages (Lodge, 2015; Mullen, 2015) but the group released some captured Kurdish children and civilians in exchange for their captured fighters by the YPJ (UNHRC, 13 August 2014: 8; UNHRC, 12 February 2014: 10). The ISIS fighters took some enslaved Yazidi women and girls to Syria either as their wives or slaves to provide them with sexual service (UNHRC, 14 November 2014: 9; UNHRC, 5 February 2015: 49) but they did not enslave any people there.

The group, similarly to its war prisoners in Iraq, executed most of its Syrian prisoners captured during conflicts for merely fighting them. Based on the report of the UNHRC, public executions were the common spectacle of Fridays in the areas under the control of the group (UNHRC, 13 August 2014: 7).

The ISIS fighters beheaded hundreds of captured fighters and civilians, some were under 18 years old, in Aleppo and al-Raqqah from February 2014 to April 2014 (UNHRC, 13 August 2014: 7). The group also executed more than 200 government soldiers after controlling a military airbase in Tabqa, al-Raqqah in late August 2014 (UNHRC, 14 November 2014: 11-12; UNHRC, 5 February 2015: 29; Westall and Karouny, 2014). According to the UNHRC, the ISIS fighters killed 350 people after seizing 
the Sha'ar gas field in Homs in July 2014 (UNHRC, 14 November 2014: 12). Among the victims, 200 were government soldiers (Alhamadee, 2014).

ISIS cut the throat of a captured YPG female fighter in Tal Abyad in mid-September 2014 (UN HRC, 14 November 2014: 12). The group executed a fighter from SDF, a man and his son after capturing them in February 2016 for being SDF's informants (UNHRC, 11 August 2016: 1213). The UNHRC further reported the burning of about four YPG's fighters alive in March 2016 (UNHRC, 11 August 2016:13).

In February 2015, ISIS released a video showing that the Jordanian pilot Muath al-Kasasbeh, arrested in al-Raqqah in December 2014, was being burnt to death (Video: ISIS burns Hostage, 2015). The group also burnt two captured Turkish soldiers alive in Aleppo in December 2016 (Watch: ISIS releases Video, 2017).

\section{Conclusion}

Humanitarian law is a set of rules and customs which are applicable during armed conflict to protect noncombatants and mitigate fatal effects of war through the prohibition of certain methods of warfare. The origins of the law date back to the ancient religions and civilizations. Hence, Islam can be studied as a significant precedent of modern international humanitarian law.

Islam is primarily based on the Quran and traditions of the prophet Muhammad. The two sources entail various humanitarian rules that they played effective roles during battles for many centuries. The Quran includes many verses as to the treatment of prisoners of war. The verses guide Muslims to capture combatants after they defeat their belligerent armies and before the termination of war. They advise Muslims to treat prisoners with dignity, kindness and generosity. The verses further clarify to Muslims that the fate of prisoners should be release either out of grace or for ransom. The teachings and practices of the prophet Muhammad are similarly a significant humanitarian guidance as to the treatment of war prisoners. The prophet captured many prisoners based on the Quranic permission during the battles took place in his life time. He treated them as humanly as the Quranic verses required. He eventually released all either unconditionally or upon ransom for money or a service. The Quran though never mentions enslavement regarding war prisoners; Muslims enslaved them many times during their battles. However, the notion and reason of enslavement by Muslims was seemingly different from slavery practiced outside of the Islamic world. Muslims used the common practice of enslavement to integrate non-Muslims into the Islam society. They usually treated them in a way that they themselves wanted to be treated, fed them from what they themselves used to eat, clothe them from what they themselves had to wear and freed them when they were not harmful to the communities. The prophet never executed 
prisoners except the ones charged with crimes and dishonesty against Muslims.

ISIS is a radical Islamic group that captured large areas from the territory of Iraq and Syria between 2013 and 2014. The group committed serious atrocities of concern to mankind in the course of its military campaigns against the two countries. One of the most heinous atrocities of the group was the mistreatment and execution of war prisoners. The group captured many civilians and combatants from the Iraqi and Syrian armed forces, Syrian rival groups and Iraqi and Syrian Kurdish forces. The group tortured prisoners in the most inhuman methods including whipping, electrocuting, suspending them by their arms from walls and surrounding them with psychological horror. ISIS carried out mass executions of the prisoners for taking part in battle against its fighters. The methods of the group's execution varied from shooting and beheading to hanging and burning alive. There is, however, not a clear statistic as to the number of the victims; the number exceeds tens of thousands.

The author argues that the war of ISIS is quite offensive namely to Muslims and therefore it can never be justified by the Quranic verses and traditions of the prophet Muhammad as jihad. The group never adhered the humanitarian rules prescribed in the Quran and traditions of the prophet Muhammad specifically regarding the prisoners of war. The Quran and the prophet thoroughly prohibited Muslims from torturing pagan prisoners but ISIS tortured Muslims in the most brutal ways. The Quran and the prophet never allowed the execution of pagan prisoners for merely participating in battles against Muslims but ISIS carried out such a punishment for such a reason against Muslims. The ISIS treatment of war prisoners looks more like the treatment of armies fought Muslims rather than the treatment of Muslims against others. Therefore, the group is responsible for its atrocities against war prisoners in Iraq and Syria.

\section{References:}

1. Al-Buti, Muhammad Said R., Jihad fil Islam, (Beirut: Dar alFikr,1995).

2. Alhamadee, Mousab, "Syria fights to free Gas Field from Islamic State", The Sacramento Bee, (19 July 2014). Available at: <http://www.sacbee.com/news/nation-world/article2604328.html $>$ (Accessed:16 July 2017).

3. Ali, Sayed Ameer, The Spirit of Islam: A History of the Evolution and Ideals of Islam with a life of the Prophet, (New York: Cosimo Classics, 2010). 
4. Al-Mubarakpuri, Safi-ur-Rahman, Ar-Raheeq al-Makhtum: The biography of the Noble Prophet, $1^{\text {st }}$ ed., (Riyadh et al: Dar-us-Salam, 1996).

5. Al-Tabarani, Sulaiman bin Ahmad, Mu'jam al-Kabeer, (Riyadh: Dar al-Samihi, 1994).

6. Amnesty International, "Syria: Harrowing Torture, Summary Killings in Secret ISIS Detention Centers", (19 December 2013). Available at:<https://www.amnesty.org/en/latest/news/2013/12/ syriaharrowing-torture-summary-killings-secret-isis-detentioncentres/>(Accessed: 7 June2017).

7. Amnesty International, "The State of the World's Human Rights: Report 2014/2015", 2015.

8. Bennoune, Karima, "As-Salāmu 'Alaykum? Humanitarian Law in Islamic Jurisprudence", Michigan Journal of International Law, Vol. 15, 1994, pp. 605-643.

9. Bunzel, Cole, From Paper State to Caliphate: The Ideology of the Islamic State, Center for Middle East Policy at BROOKINGS, (March 2015).

10. Dahlan, Ahmad b. Zayni, al-Sirah al-Nubawiyyah, $1^{\text {st }}$ ed., Vol. 2, (Halb: Dar al-Qualam al-'Arabi, 1417/1996).

11. Doi, Abdur Rahman I., Non-Muslims Under Shari'ah (Islamic Law), (London: Taha Publishers, 1983).

12. Ennaji, Mohammed, Slavery, the State and Islam, Translated by: Teresa Lavender Fagan, (Cambridge et al: Cambridge University Press, 2013).

13. Gilsinan, Kathy, "The Many Ways to Map the Islamic 'State'", The Atlantic, (27 August 2014). Available at: <https://www.theatlantic.com/international/archive/2014/08/themany-ways-to-map -the-islamic-state/379196/> (Accessed: 3 May 2017).

14. Hashim, Ahmed S., From Al-Qaeda Affiliate to the Rise of the Islamic Caliphate: The Evolution of the Islamic State of Iraq and Syria (ISIS), Policy Report, S. Rajaratnam School of International Studies (Nanyang Technological University), (December 2014).

15. Human Rights Watch, "Iraq: ISIS abducting, killing, expelling Minorities", (19 July 2014). Available at: <https://www.hrw.org/news/2014/07/19/iraq-isis-abducting-killingexpelling-mino rities> (Accessed: 10 June 2017).

16. Human Rights Watch, "Iraq: ISIS Execution Site Located", (26 June 2014). Available at: <https://www.hrw.org/news/2014/06/26/iraqisis-execution-site-located $>$ (Accessed: 12 June 2017). 
17. Ibn Ishaq, The life of Muhammad, Translated by: A. Guillaume, (Oxford et al: Oxford University Press, 2004).

18. "Islamic State Video purports to show Kurdish Peshmerga Beheadings", Reuters, (30 March 2015). Available at: $<$ http://www.reuters.com/article/us-mideast-crisis-islamicstate-

beheading/isl amic-state-video-purports-to-show-kurdish-peshmergabeheadings-idUSKBNOMG0VH2015032 0> (Accessed: 13 June 2017).

19. Jâmi' at-Tirmidhi, Translated by Abu Khaliyl, Vol. 3, (Riyadh et al: Darussalam, 2007).

20. Kabbani, Shaykh Muhammad Hisham, "What is Jihad? A Scholar's Prospective", History of Islam. Available at: <https://historyofislam.com/contents/the-modern-age/what-is-jihada-schola rs-perspectiv/|> (Accessed: 7 May 2017).

21. Khan, Q.S., How to Prosper the Islamic Way, $1^{\text {st }}$ ed., (Mumbai: Tanveer Publication, 2011).

22. Kister, M.J., "The Massacre of the Banu Qurayza: A Re-examination of a Tradition", Jerusalem Studies in Arabic and Islam, Vol. 8, 1986, pp. 61-96.

23. Lodge, Carey, "ISIS 'demand \$30m Ransom for Assyrian Hostages", Christian Today, (10 April 2015). Available at: <https://www.christiantoday.com/article/isis.demand.30m.ransom.for . assyria n.hostages/51831.htm> (Accessed: 13 June 2017).

24. Mamoun, Abdelhak, "Urgent Video: ISIS beheads Kurdish Soldiers, broadcasts Video from Downtown Mosul", Iraqi News, (29 August 2014). Available at: <https://www.iraqinews. com/iraq-war/urgentisis-beheads-kurdish-soliders-broadcasts-video-downtown-mosul/> (Accessed: 12 June 2017).

25. Mourtada, Hania and Gladstone, Rick, "Iraq's Branch of Al Qaeda Merges with Syria Jihadists", The New York Times, (9 April 2013). Available at: <http://www.nytimes.com /2013/04/10/world/middleeast/Iraq-and-Syria-jihadists combine.html> (Accessed: 1 June 2017).

26. Mullen, Jethro, "ISIS' High-Profile Hostages", CNN, (11 February 2015). Available at: <http:// edition. cnn.com/2015/02/11/world/isishostages/> (Accessed: 13 June 2017).

27. Munir, Muhammad, "Debates on the Rights of Prisoners of War in Islamic Law”, Islamic Studies, Vol. 49, Issue 4, 2010, pp. 463-492.

28. Munir, Muhammad, The Protection of Civilians in War: Noncombatant Immunity in Islamic Law War, International Islamic University Islamabad, 2011. 
29. Musnad Imam Ahmad Bin Hanbal, Translated by: Nasiruddin alKhattab, Vol. 1, (Riyad et al, Darussalam, 2012).

30. Șahīh al-Bukhārī, Translated by: Muhammad Muhsin Khan, Vol. 4, 5, (Riyadh et al: Darussalam, 1997).

31. Sahih Muslim, Translated by: Nasiruddin al-Khattab, Vol. 4, 5, 6, (Riyadh et al: Darussalam, 2007).

32. Shammas, John, "ISIS Monsters use Torture Technique 'The flying Carpet' to force Prisoners to confess", Mirror, (22 July 2016). Available at: <http://www.mirror.co.uk/news/world-news/isismonsters-using-spine-snapping-8471128> (Accessed: 9 June 2017).

33. Siddiqi, Muhammad Yasin Mazhar, "Role of Booty in the Economy during the Prophet's Time", Journal of King Abdulaziz University: Islamic Economics, Vol. 1, 1989, pp. 83-115.

34. Sunan Abu Dawd, Translated by Nasiruddin al-Khattab, Vol. 3, (Riyad et al: Darussalam, 2008).

35. Sunan Ibn Mâjah, Translated by: Nasiruddin al-Khattab, Vol. 3, (Riyadh et al: Darussalam, 2007).

36. The Geneva Convention for the Amelioration of the Condition of the Wounded and Sick in Armed Forces in the Field (Geneva Convention I), (adopted 22 August 1864, entered into force 22 June 1865), 940 TS 377.

37. The History of al-Tabari (Ta'rikh al-rusul wa 'l-muluk), Translated by M v McDonald, Vol. VII, VIII, (New York: State University of New York Press, Albany, 1987).

38. The Quran.

39. "The Revival of Slavery Before the Hour", Dabiq, Issue. 4, 1435 (2014), pp. 14-15. Available at: $<$ https://clarionproject.org/docs/islamic-state-isis-magazine-Issue4-the-failed-crusade.pdf $>$ (Accessed: 10 June 2017).

40. "This is the Promise of Allah", in Al Jazeera, Sunni Rebels declare New 'Islamic Caliphate', (30 June 2014). Available at: <http://www.aljazeera.com/news/middleeast/2014/06/isil-declaresnew-islamic-caliphate-20146291732 6669749.html> (Accessed: 2 June 2017).

41. United Nations Assistance Mission for Iraq (UNAMI) and Office of the High Commissioner for Human Rights (OHCHR), "Report on the Protection of Civilians in the Non International Armed Conflict in Iraq: 5 June - 5 July 2014".

42. UNAMI and OHCHR, "Report on the Protection of Civilians in the Armed Conflict in Iraq: 6 July-10 September 2014".

43. UNAMI and OHCHR, "Report on the Protection of Civilians in the Armed Conflict in Iraq: 11 December 2014-30 April 2015”. 
44. UNAMI and OHCHR, "Report on the Protection of Civilians in the Armed Conflict in Iraq: 1 May-31 October 2015".

45. UNAMI and OHCHR, "A Call for Accountability and Protection: Yazidi Survivors of Atrocities committed by ISIL”, (August 2016).

46. United Nations Human Rights Council (UNHRC), "Report of the Independent International Commission of Inquiry on the Syrian Arab Republic", (14 November 2014).

47. UNHRC, "Report of the Independent International Commission of Inquiry on the Syrian Arab Republic", A/HRC/25/65, (12 February 2014).

48. UNHRC, "Report of the Independent International Commission of Inquiry on the Syrian Arab Republic”, A/HRC/27/60, (13 August 2014).

49. UNHRC, "Report of the Independent International Commission of Inquiry on the Syrian Arab Republic", A/HRC/28/69, (5 February 2015).

50. UNHRC, "Report of the Independent International Commission of Inquiry on the Syrian Arab Republic", A/HRC/33/55, (11 August 2016).

51. Varghese, Johnlee, "ISIS lists out 5 Islamic Reasons to justify Beheading Alan Henning and Other Captives", International Business Times, (6 October 2014). Available at: <http://www.ibtimes.co.in/isis-lists-out-5-islamic-reaso ns-justifybeheading-alan-henning-other-captives-610585> (Accessed:10 June 2017).

52. "Video: ISIS burns Hostage alive", Fox News, (3 February 2015). Available at: <http://video.foxnews.com/v/4030 583977001/?\#sp=show-clips $>$ (Accessed: 16 June 2017).

53. "Watch: ISIS releases Video of burning 2 Caged Turkish Soldiers to Death in English", Heavy News, (2 January 2017). Available at: <http://heavy.com/news/2017/01/isis-islamic-state-amaq-news-thecross-of-the-shield-turkey-turkish-soldiers-burned-to-deathexecution-wilayat-halab-aleppo-syria-english-translation-subtitlesvideo/> (Accessed: 16 June 2017).

54. Westall, Sylvia and Karouny, Mariam, "Video shows Islamic State executes Scores of Syrian Soldiers" Reuters, (28 August 2014). Available at: <http://www.reuters.com/article/us-syria-crisisidUSKBN0GS10O20140828> (Accessed: 16 June 2017).

55. Yamani, Ahmed Z., "Humanitarian International Law in Islam: A General Outlook", Michigan Year Book of International Legal Studies, Vol. 7, 1985, pp. 189-215. 
56. Zelin, Aaron Y., The War between ISIS and al-Qaeda for Supremacy of the Global Jihadist Movement, The Washington Institute for Near East Policy, (June 2014). 